\title{
A NEW TALL AND EXCEPTIONAL SPECIES OF LEPANTHES FROM NORTH-WEST ECUADOR (ORCHIDACEAE: PLEUROTHALLIDINAE)
}

\author{
Luis E. Baquero ${ }^{1,3}$ \& Marco F. Monteros ${ }^{2}$ \\ ${ }^{1}$ Grupo de Investigación en Medio Ambiente y Salud BIOMAS, Carrera de Ingeniería \\ Agroindustrial y Alimentos, Facultad de Ingeniería y Ciencias Agropecuarias, \\ Universidad de Las Américas, Calle José Queri, Quito 170137, Pichincha, Ecuador \\ ${ }^{2}$ Fundacion EcoMinga, 27012 de noviembre and Luis A Martínez, Baños, Tungurahua, Ecuador \\ ${ }^{3}$ Author for correspondence: lbaquero@hotmail.com
}

\begin{abstract}
A new and spectacular species of Lepanthes from north-west Ecuador is presented here. Lepanthes tulcanensis belongs to the Marsipanthes subgenus and is similar to L. niesseniae in the same subgenus, with an inflorescence that does not reach the tip of the leaves, and flowers with shallower synsepal compared to the rest of the species in the subgenus. Nevertheless, the plants of $L$. tulcanensis are, by far, the largest among the species of the subgenus and among the largest in the genus.

Resumen. Se presenta una nueva y espectacular especie de Lepanthes del noroeste de Ecuador. Lepanthes tulcanensis pertenece al subgénero Marsipanthes y es similar a $L$. niesseniae perteneciente al mismo subgénero, con inflorescencias que no llegan al borde de la hoja, así como un sinsépalo no tan profundo, comparados con el resto de especies del subgénero. Sin embargo, las plantas de L. tulcanensis son las más grandes del subgénero y una de las más grandes del género.
\end{abstract}

Keywords/Palabras clave: EcoMinga, Lepanthes lucifer, Lepanthes niesseniae, Marsipanthes, Reserva Dracula

Introduction. The genus Lepanthes Sw., a highly diverse genus of Neotropical orchids, with more than 1100 species, and new species being frequently discovered in Ecuador, is divided into two subgenera: Lepanthes and Marsipanthes (Baquero 2018, Baquero et al. 2018, Baquero et al. 2019, Karremans 2016, Luer \& Thoerle 2011, Luer 1996, Thoerle \& Hirtz 2015, Tobar et al. 2018, Zambrano \& Solano 2019).

The genus Lepanthes has plants with ramicauls enclosed by lepanthiform sheaths, flowers with transversely expanded petals, fleshy or membranaceous, with two or three lobes, and the lip two or three lobed (Luer 1996). Most plants of Lepanthes subgenus Lepanthes have a complex lip with a body connecting a pair of blades which normally embrace the column, and a very small structure at the base of the lip called the appendix (Luer 1996, Blanco \& Barboza 2005). In 1986, the subgenus Marsipanthes was proposed by Luer to accommodate three atypically saccate-flowered species (with the sepals forming a pouch). In 1996, in his monograph of the genus, Luer added four more species to subgenus Marsipanthes and presented a key to its species and sections (Luer 1986, 1996). All the species in the subgenus have more or less saccate flowers with fleshy instead of membranaceous petals, which are born from a peduncle lying on top of the leaf, with the successively flowered raceme reaching the tip or beyond (Luer 1996). In 2003, another species of Lepanthes is added to the Marsipanthes subgenus and described as L. niesseniae Luer. This is the only species of Marsipanthes in which the peduncle and flower raceme do not reach the tip of the leaf and the flowers are not saccate (Luer \& Thoerle 2012).

Recently, in a poorly explored forest from north-west Ecuador protected by EcoMinga Foundation, a new and spectacular species of Lepanthes was discovered. The species belongs to subgenus Marsipanthes and shares, together with L. niesseniae, a peduncle and flower raceme which are shorter than the leaf and with very large plants for the subgenus. The new species is described here. 


\section{TAXONOMIC TREATMENT}

Lepanthes tulcanensis Baquero \& M.F.Monteros, sp. nov. (Fig. 1-4).

TYPE: Ecuador. Carchi: Reserva Dracula, 2043 m, 15 September 2018, Marco Monteros MFM201 (holotype: QCNE).

Diagnosis: Lepanthes tulcanensis is most similar to $L$. niesseniae, sharing the elliptical ovate leaves suffused with purple, the inflorescence with the flower shorter than the length of the leaves, and the shallower flowers compared to the rest of the species in the subgenus. Lepanthes tulcanensis differs from $L$. niesseniae in the upper lobe of the petals sub-rectangular to oblong, convex, slightly concave towards the central vein, covered with a velvety texture, and the lower lobe narrowly triangular, with the apex hispid $v s$. the upper lobe of the petals oblong and bosselated, and the lower lobe curved and rounded at the apex, the lip velvety with the appendix triangular and acute $v s$. the bossellated and verrucose lip with a narrowly oblong appendix in L. niesseniae.

Plant epiphytic, sympodial, caespitose herb up to $40 \mathrm{~cm}$ tall. Roots ca. $0.8 \mathrm{~mm}$ in diameter. Ramicauls slender, arcuate to horizontal, elongated, thin, $25-35 \mathrm{~cm}$ long, enclosed by long-acuminate, coarse, apiculate at the margins, loose lepanthiform sheaths, 1.8-2.5 long. Leaf green suffused with purple, thinly coriaceous, conduplicate and reticulate, ovate, the base slightly cuneate, the apex $2.5 \mathrm{~mm}$, long-acuminate, $10-13 \times 5.5-7.0 \mathrm{~cm}$. Inflorescence congested, 1 to several, successively, many-flowered racemes up to 30-50 $\mathrm{mm}$ long, born on top of the leaf by a slender peduncle $20-40 \mathrm{~mm}$ long; floral bracts oblique, acuminate, $17-20 \mathrm{~mm}$ long; pedicels $5 \mathrm{~mm}$ long. Ovary costate, $5 \mathrm{~mm}$ long. Flower with sepals translucent yellow suffused with orange, with a dark red blotch at the dorsal sepal and three red blotches towards the center of each lateral sepal and petals yellow, yellowish-green, suffused with brown towards the margins of the upper lobe, column red, and lip yellow suffused with yellowish-green, sanguine red at the margins of the lobes, anther cap rose. Sepals carinate along the veins on the abaxial surface. Dorsal sepal broader and longer than the lateral sepals, broadly ovate, shallowly concave, 7-veined, minutely ciliate at the margin, caudate, 9.3 $\times 8.5 \mathrm{~mm}$, including a $3.2 \mathrm{~mm}$ long tail, connate to the lateral sepals for $2 \mathrm{~mm}$. Lateral sepals broadly ovate, 4-veined (each lateral sepal), oblique, minutely ciliate at the margins, caudate, connate $4.5 \mathrm{~mm}$ into a shallow cup, $9.5 \times 11.0 \mathrm{~mm}$, including a $3 \mathrm{~mm}$ long tail, each individual sepal free for $c a .5 \mathrm{~mm}$. Petals transversely bilobed, velvety, the upper lobe sub-rectangular to oblong, convex, slightly concave towards the midline and apex of the petal, rounded and hispid at the apex, $1.7 \times 0.8 \mathrm{~mm}$ long, the lower lobe narrowly triangular, slightly convex, obtuse and hispid at the apex, $1.5 \times 0.6 \mathrm{~mm}$ long, the upper lobe rounded and the lower lobe straight where the lobes meet at the midline forming an acute angle between them. Lip velvety, transversely bilobed, with the lobes broadly cuneate, auriculate, oblique, flanking the column, forming a narrow body, connate to the base of the column, the frontal part of each lobe hispid towards the anther, with a triangular, acute, bristled appendix with an echinaceous and globose structure at the sinus, $1.7 \times 2.0 \mathrm{~mm}$. Column subterete, 1.3 $\mathrm{mm}$ long, the anther apical and stigma ventral, the viscidium bent upwards, the apex of the rostellum elongate, acute. Anther cap cucullate, obovate, 0.4 $\mathrm{mm}$ long. Pollinia 2, yellow, pyriform, attached to a detachable viscidium, $0.4 \mathrm{~mm}$ long. Capsule not observed.

Eponymy: Named in honor of the Tulcán township in north-west Ecuador where it was discovered.

Habitat AND ECOlogy: Lepanthes tulcanensis is so far endemic to a relatively small area in northwestern Ecuador, close to the border with Colombia. A population of three plants from a first locality were

Right, Figure 1. Comparison of the most similar species and other species of the Marsipanthes subgenus to Lepanthes tulcanensis Baquero \& M.F.Monteros. A. Lepanthes tulcanensis (leaf and flower view, in situ). B. Lepanthes tulcanesis (flower frontal view). C. Lepanthes niesseniae (flower frontal view). D. Lepanthes quadricornis (flower frontal view). E. Lepanthes ribes (flower frontal view). F. Lepanthes lucifer (flower frontal view). Photographs by Marco F. Monteros (A, B and E from the holotype MFM 201, QCNE), and Luis E. Baquero (C, D and F). 

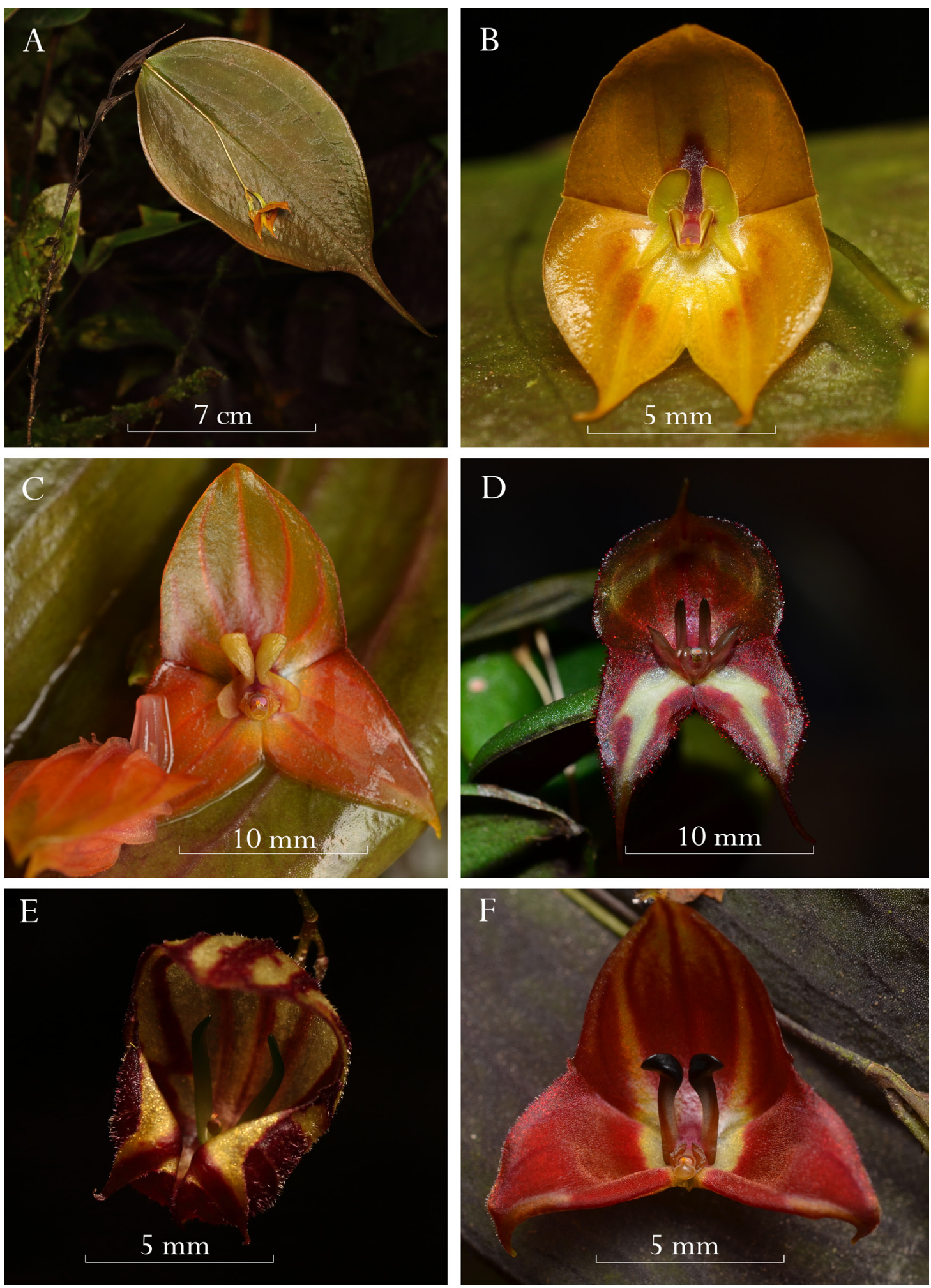


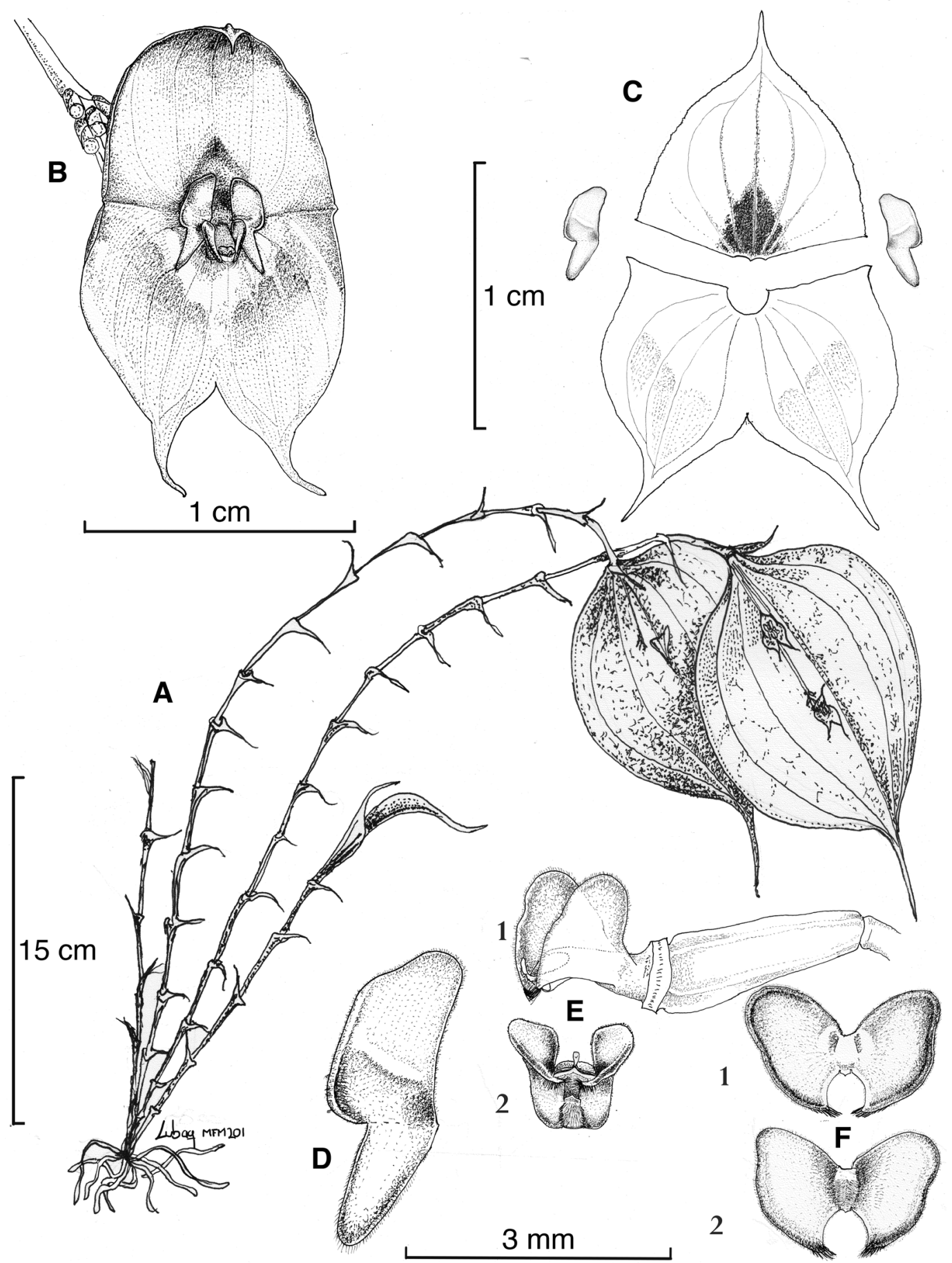

FIgURE 2. Illustration of Lepanthes tulcanensis Baquero \& M.F.Monteros. A. Habit. B. Flower. C. Dissected perianth. D. Petal. E1. Lateral view of lip and ovary. E2. Frontal view and lip column. F1. Lip in expanded position, adaxial view. F2. Lip in expanded position, abaxial view. Drawn by Luis E. Baquero from the plant that served as the holotype (MFM 201, QCNE). 

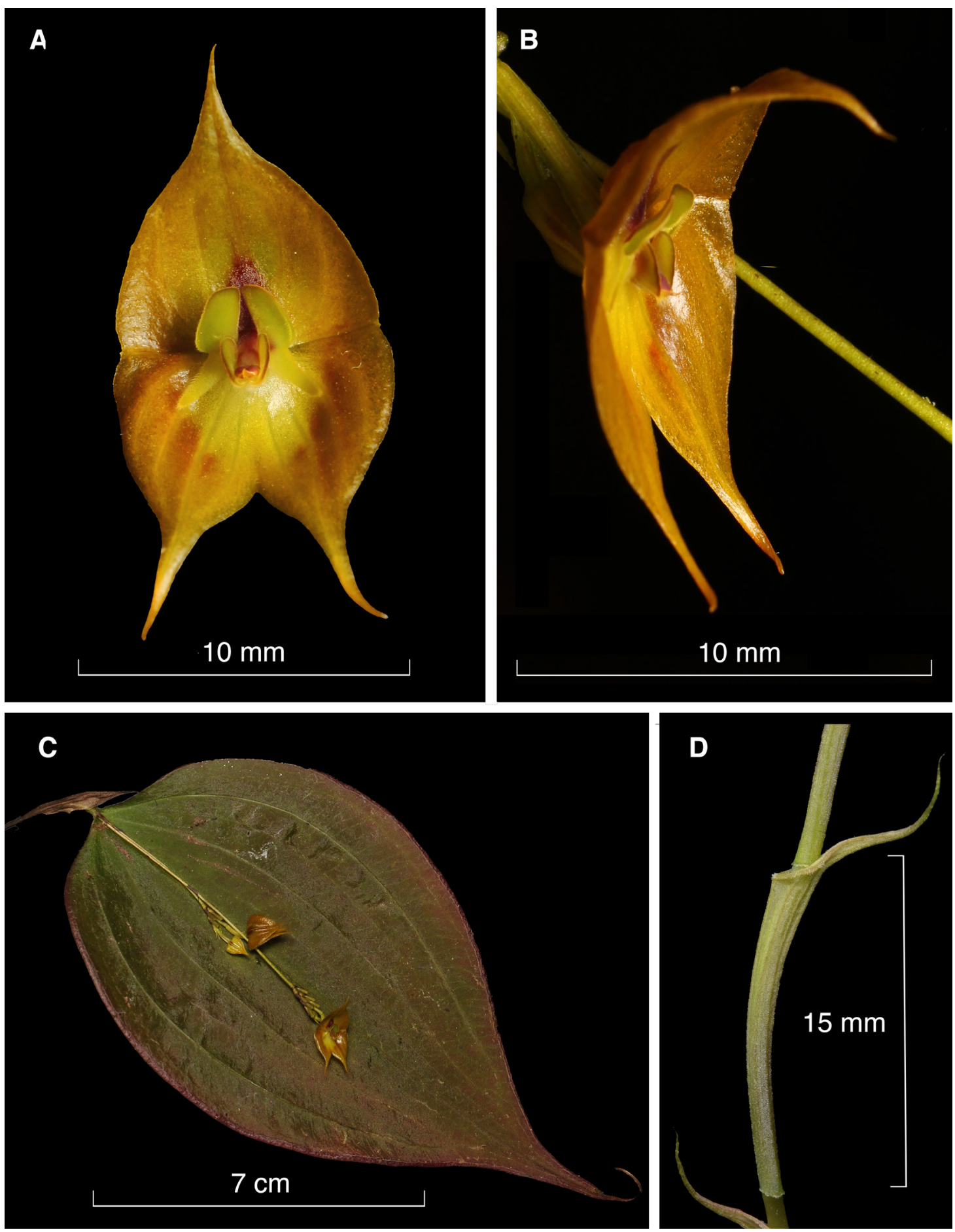

Figure 3. Lepanthes tulcanensis Baquero \& M.F.Monteros. A. Flower, frontal view. B. Flower, 3/4view. C. Leaf from dorsal view. D. Lepanthiform sheath. Photographs by Marco F. Monteros (A-C from the holotype MFM 201, QCNE), and Luis E. Baquero (D). 
found growing in an extremely moist cloud-forest at an unexplored area within the Dracula Reserve at around $2000 \mathrm{~m}$ in elevation. One of the plants was collected and a division of the plant was used for the holotype. The rest of the plant was taken to the Quito Botanical Garden for ex situ culture. A few months later, another robust plant was found growing in similar conditions $11 \mathrm{~km}$ from the first group of plants. At both localities, the plants of $L$. tulcanensis were found growing low (2 $\mathrm{m})$ off the ground on wide trunks where high moisture and dappled light was constant.

PARATyPe: Ecuador. Carchi: Reserva Dracula, 2043 m, 21 October 2018, Marco Monteros MFM202 (paratype: QCNE-Spirit).

Phenology: This species has always been observed blooming at its habitat, in different months. A plant is cultured at the Quito Botanical Garden but it seems to need higher moisture for the leaves to develop in optimal condition, and no flowers have appeared since the plant was taken to Quito.

Lepanthes tulcanensis is a member of subgenus Marsipanthes considering the dorsal sepal with seven veins and lateral sepals with more than four veins -eight in total-, thick and fleshy petals, the bilobed lip without blades, the shallowly cupped flowers and the inflorescence with a long peduncle and congested raceme which rests at the adaxial side of the leaf. This species is, perhaps, the most atypical species of the subgenus Marsipanthes since it has much larger plants (close to $40 \mathrm{~cm}$, including the leaf) and bigger leaves (with a long acuminate apex) than any other member of the subgenus. From a distance, $L$. tulcanensis resembles L. rhodopylla Schltr. due to the large plants with dark, reticulated, acuminate leaves. Nevertheless, the flowers are completely different not only from $L$. rhodopylla but from any other species in the genus, based on the inflorescence which is born at the adaxial side of the leaf, the dorsal sepal with 5 veins, and 8-veined synsepal, the bilobed lip without blades, the shallowly cupped flowers and the fleshy petals (Fig. 1-4).
Conservation status. Two healthy populations have been found over the years near the location where it was initially discovered in Carchi province in northwest Ecuador. Nevertheless, a few plants have perished since the first population was discovered in September of 2018. These plants apparently died due to the harsh summer of 2019. Another threat for the populations of this species and the species itself (as far as we know about it) is that the area where all the populations of this species are known from is now affected by mining activity. We suggest to place it under the IUCN category "Critically Endangered - CR", under criteria B1, considering an extent of occurrence of less than 100 square km with only two known locations (a) and a continued decline observed (b) since the species is strongly affected by mining activity and, it might perish in the next years if mining activity is not controlled.

ACKNOWLEDGEMENTS. The authors acknowledge Fundación EcoMinga for funding research on new and endangered species in north-west Ecuador in the area around its Dracula Reserve, which it protects and continues to expand to other areas. We acknowledge Universidad de Las Americas (UDLA) for funding orchid research in Ecuador. We thank Tatiana Jaramillo, Quito Botanical Garden technical director, for making it possible to grow a living plant of the new species. We thank Rainforest Trust (US) for supporting the conservation of the habitat of this species. The Ministerio del Ambiente del Ecuador is acknowledged for issuing the Environmental Research Permit No. 008-2016-IC-FLO-DNB/MA.

\section{Literature Cited}

Baquero, L. E. (2018). A new species of Lepanthes (Orchidaceae: Pleurothallidinae) from northwestern Ecuador. Phytotaxa, 343(1), 75-81.

Baquero, L. E., Moreno, J. S. \& Iturralde, G. A. (2018). The Four Footed Lepanthes (Pleurothallidinae), a new species from north-western Ecuador. Lankesteriana, (18)3, 183-188.

Baquero, L. E., Jaramillo-Vivanco, T. \& Galarza Verkovith, D. (2019). A new and showy species of Lepanthes (Orchidaceae: Pleurothallidinae) from North-Western

Right, Figure 4. Details of Lepanthes tulcanensis Baquero \& M.F.Monteros. A. Petals and lip, frontal view. B. Petals and lip, $3 / 4$ view. C. Lip and sinus, frontal view. D. Apex of the lip and the sinus, Frontal view. E. Hispid hairs at the tip of the lobes from the lip. Photographs by Marco F. Monteros (A-B), and Luis E. Baquero (C-E from paratype MFM 202, QCNE). 

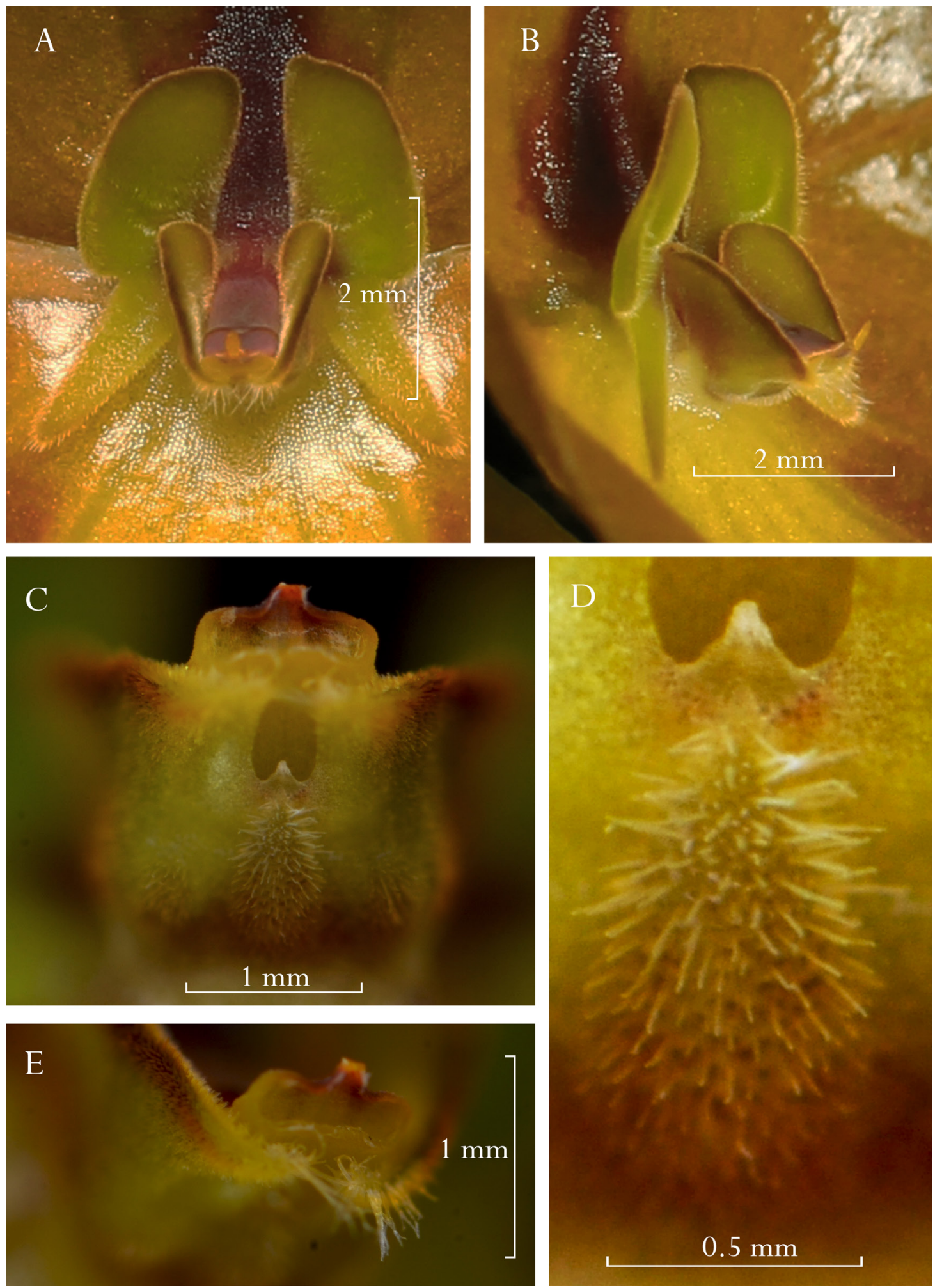
Ecuador. Lankesteriana, 19(2), 99-105.

Blanco, M. A. \& Barboza, G. (2005). Pseudocopulatory Pollination in Lepanthes (Orchidaceae: Pleurothallidinae) by Fungus Gnats. Annals of Botany, 95(5), 764-772.

Karremans, A. P. (2016). Genera Pleurothallidinarum: an updated phylogenetic overview of Pleurothallidinae. Lankesteriana, 16(2), 219-241.

Luer, C. A. (1986). Icones Pleurothallidinarum. I. Systematics of the Pleurothallidinae. Monographs in Systematic Botany from the Missouri Botanical Garden, $15,32-34$.

Luer, C. A. (1996). Icones Pleurothallidinarum. XIV. Systematics of Draconanthes, Lepanthes subgenus Marsipanthes and subgenus Lepanthes of Ecuador. Monographs in Systematic Botany from the Missouri Botanical Garden, 61, 1-255.

Luer, C. A. \& Thoerle, L. (2011). Lepanthes Sw. and affiliates. In C. Persson \& B. Stahl, Flora of Ecuador,
88, 13-405. Goteborg: Botanic Institute, Goteborg University.

Luer, C.A. \& Thoerle, L. (2012). Icones Pleurothallidinarum. XXXII. Lepanthes of Colombia (Orchidaceae). Monographs in Systematic Botany from the Missouri Botanical Garden, 123, 1-296.

Thoerle, L. \& Hirtz, A. (2015). Three new Lepanthes species (Pleurothallidinae, Orchidaceae) from Ecuador. Phytotaxa, 201, 50-62.

Tobar, T., López, M. F., Muñoz-Upegui, D. \& Richter, F. (2018). Two new species of Lepanthes (Pleurothallidinae; Orchidaceae) from Andean forest remnant in Ibarra, Ecuador. Phytotaxa, 375(3), 221228.

Zambrano, B. \& Solano, R. (2019). Two new Pleurothallidinae (Orchidaceae) from Southwestern Ecuador: Acianthera pustulata and Lepanthes marioi. Phytotaxa, 422(3), 255-272. 